DOI: https://doi.org/10.15688/jvolsu4.2017.2.3

UDC 94(497.5)

Submitted: 23.11 .2016

LBC 63.3(4Xop)

Accepted: 14.03 .2017

\title{
GOTHICISM IN CROATIA: FROM THE MIDDLE AGES TO MODERN TIME ${ }^{1}$
}

\author{
Denis E. Alimov
}

Saint Petersburg State University, Saint Petersburg, Russian Federation

\begin{abstract}
The article deals with the genesis and evolution of the notion of the supposed Gothic origins of the Croats or their close bonds with the Goths, which existed in medieval and early modern historiography. While examining this complex of ideas in the context of the so-called Gothicism, that is ideologically motivated apellation to the Goths and their legacy that was characteristic for medieval and early modern Europe, the author focuses on the historical specificity of the Croatian Gothicism and changes it has undergone in the course of its evolution from the Middle Ages to the late 17th century. The author concludes that the Croatian Gothicism was not a stable ideological construction, but a complex phenomenon, not connected exclusively with the tasks of glorification of a nation or a state. The emergence of Gothicism in this region in the early Middle Ages was connected with the ethnic discourse of Roman-speaking urban inhabitants of the Adriatic coast who ascribed the Gothic origin to the Slavs of the hinterland. In the late Middle Ages the idea of the Gothic origins was adopted by the Croats themselves for the political legitimization of the Croatian kingdom. However, in the framework of this concept the Croats were considered as autochthonous inhabitants who were under the rule of the Gothic dynasty. In the Renaissance the idea of the Gothic origins was conceptualized in the categories of the proto-national discourse. In the Dalmatian historiography the Goths began to be interpreted as a Slavic nation, and their past, along with the history of ancient Illyricum, was used to glorify the Slavs. In the 17th century the proto-national interpretation of the Goths served as a basis for the integration of the "Gothic legacy" into the Croatian national ideology in the true sense of the word.

Key words: Dalmatia, Croatian kingdom, Gothicism, Illyrianism, proto-national discourse.

Citation. Alimov D.E. Gothicism in Croatia: from the Middle ages to Modern time. Vestnik Volgogradskogo gosudarstvennogo universiteta. Serija 4, Istorija. Regionovedenie. Mezhdunarodnye otnoshenija [Science Journal of Volgograd State University. History. Area Studies. International Relations], 2017, vol. 22, no. 2, pp. 25-34. (in Russian).
\end{abstract}

УДК 94(497.5)

Дата поступления статьи: 23.11.2016

ББК 63.3(4Хор)

Дата принятия статьи: 14.03.2017

\section{ГОТИЦИЗМ В ХОРВАТИИ: ОТ СРЕДНЕВЕКОВЬЯ К НОВОМУ ВРЕМЕНИ ${ }^{1}$}

\section{Денис Евгеньевич Алимов}

Санкт-Петербургский государственный университет, г. Санкт-Петербург, Российская Федерация

Аннотация. В статье рассматриваются генезис и эволюция представлений о готском происхождении хорватов или о тесной связи между хорватами и готами, отразившихся в историографии Средневековья и раннего Нового времени. Рассматривая данный комплекс представлений в контексте характерного для средневековой и раннемодерной Европы готицизма - идеологически мотивированной апелляции к готам и гот- 
скому наследию, автор фокусирует внимание на исторической специфике хорватского готицизма и изменениях, которые он претерпел в своем развитии от Средневековья до конца XVII века. Автор заключает, что хорватский готицизм не был стабильной идеологической конструкцией, а был сложным феноменом, не связанным лишь с задачами глорификации народа или государства. Зарождение готицизма в данном регионе в раннее Средневековье было связано с этническим дискурсом живших в прибрежных городах Адриатики романоязычных жителей, которые приписывали готское происхождение жившим в хинтерланде славянам. В позднее Средневековье идея готского происхождения была усвоена самими хорватами для политической легитимизации Хорватского королевства, однако в рамках этой концепции хорваты считались автохтонными жителями, оказавшимися под властью готской династии. В эпоху Ренессанса идея готского происхождения была осмыслена в категориях протонационального дискурса. В далматинской историографии готы стали интерпретироваться как славянский народ, а их прошлое, наряду с историей античного Иллирика, было использовано для прославления славян. В XVII в. протонациональная интерпретация готов послужила основой для интеграции «готского наследия» в собственно хорватскую национальную идеологию.

Ключевые слова: Далмация, Хорватское королевство, готицизм, иллиризм, протонациональный дискурс.

Цитирование. Алимов, Д. Е. Готицизм в Хорватии: от Средневековья к Новому времени / Д. Е. Алимов // Вестник Волгоградского государственного университета. Серия 4, История. Регионоведение. Международные отношения. - 2017. - Т. 22, № 2. - С. 25-34.

Одним из ярких феноменов, характеризующих формы репрезентации средневекового прошлого в странах Европы в эпоху, предшествовавшую появлению критической историографии, является так называемый готицизм, под которым можно понимать различные формы апелляции к наследию древнего народа готов, как правило, политически мотивированные и призванные обосновать с помощью приписываемого своему народу, государству или правящей династии готского происхождения претензии на верховенство. Расцвет готицизма в историографии и общественной мысли приходится на раннее Новое время, что было неразрывно связано со становлением протонационального дискурса - способа осмысления социальной и культурной реальности в категориях новой, этноязыковой (а не сословной или сугубо политической), концепции «нации» (natio). Между тем, подобно теме Рима, никогда не покидавшей пространство исторической мысли Средневековья и лишь наполнявшейся новыми смыслами в эпоху Ренессанса, готская тема также была отнюдь не нова, особенно для тех регионов, где некогда существовали готские королевства. Так, традиция, апеллировавшая к готам, еще в Средние века присутствовала в Хорватии стране, территория которой в первой половине VI в. составляла часть Остготского королевства. Рассмотрение этой традиции в ее исторической динамике было бы полезно для осмысления готицизма как комплексного феномена, понимания того, каким образом взаи- модействовали в нем средневековые и раннемодерные элементы. Однако, несмотря на присутствие в историографии работ, посвященных тем или иным аспектам готской темы в Хорватии, сама по себе идеологическая конструкция, сближавшая хорватов с готами, не только не рассматривается в литературе как целостный феномен, но и не осмысляется в общеевропейском контексте, результатом чего является выпадение хорватского случая из большинства общих работ о готицизме. В настоящей статье будет предпринята попытка наметить этапы функционирования хорватского готицизма, сфокусировав внимание на его исторической специфике и логике развития.

Комплекс представлений о связи хорватов и готов имел два источника. Один из них это существовавшая в городе Сплит историческая традиция, согласно которой готам приписывалось разорение Салоны - центра позднеантичной Далмации, некогда оставленного жителями под натиском варваров. Впервые эта традиция была зафиксирована в Житии святого Домния, датировка которого в историографии колеблется от конца VIII до XI века [17, s. 238-239]. При описании переноса мощей святого Домния из Салоны в бывший дворец императора Диоклетиана (будущий Сплит) в Житии кратко упоминается разорение Салоны готами, которое повлекло за собой бегство ее жителей на острова и последующее переселение их в бывшую императорскую резиденцию [9, p. 288]. Спустя несколько веков данный сюжет был воспроиз- 
веден (с добавлением множества подробностей) в труде сплитского архидиакона Фомы «История архиепископов Салоны и Сплита» (середина XIII в.). Это дает основания полагать, что Житие послужило Фоме Сплитскому одним из источников при описании судьбы Салоны и становления Сплита [10, s. 190-192]. В изложении сплитского автора, готы, возглавлявляемые вождем по имени Тотила, прибыли в Далмацию «из земель Тевтонии и Полонии», причем вместе с ними в Далмацию переселились семь или восемь «знатных племен» лингонов, которые, заняв территорию горной части Далмации, смешались с жившими здесь куретами, от которых якобы происходит само имя хорватов. Таким образом, в труде Фомы Сплитского описывается рождение в хинтерланде Далмации варварского народа, компонентами которого были как пришельцы - готы и славяне-лингоны, так и автохтоны - куреты. Именно этому гетерогенному народу Фома Сплитский и приписывает разорение Салоны: подробный рассказ об этом событии начинается после описания «этногенеза», с фразы о том, как некий «вождь Гот, стоявший во главе всей Склавонии» (dux Gothus, qui toti preerat Sclauonie), собрав войско, спустился с гор и, разбив два лагеря под стенами Салоны, начал штурм города [4, с. 36].

Интересно, что, описав возникновение современных ему хорватов из смешения пришельцев с автохтонами, Фома Сплитский счел нужным специально отметить: «Многими они назывались готами и тем не менее это славяне, судя по собственному имени тех, которые пришли из Полонии или Богемии» [4, c. 35]. Из этой фразы следует, что «многие» (вероятно, современники Фомы) вообще не видели разницы между славянами, готами и хорватами. Следовательно, можно говорить о том, что традиционная оппозиция «римляне варвары» приобрела в Сплите дополнительную коннотацию: римское происхождение горожан-сплитчан противопоставлялось «варварскому», готскому, происхождению сельских жителей хинтерланда. На основании известий Фомы Сплитского можно думать, что данная оппозиция если не возникла, то, по крайней мере, была актуализирована в условиях церковного раскола, произошедшего в Хорватии во время правления короля Петра Креши- мира IV (1058-1074 гг.), когда далматинские горожане из числа сторонников реформ, провозглашенных Латеранским собором 1059 г., получили возможность презрительно именовать готами своих оппонентов - хорватов-глаголяшей, привыкших использовать в богослужении вместо латыни «варварский» (славянский) язык [13, s. 21]. Описывая перипетии данного конфликта, Фома Сплитский не только называет глаголицу «готскими письменами», но и - вопреки своей собственной концепции хорватского «этногенеза» - называет готами самих хорватов, практически используя названия «хорваты» и «готы» как синонимы [4, c. $48-50]$.

Другим источником хорватского готицизма была Летопись попа Дуклянина, созданная в середине или во второй половине XII в. в г. Баре (Черногория) кем-то из среды местного духовенства. В этом памятнике, вписывающимся в рамки жанра «gesta regum», повествуется о деяниях дуклянских правителей XI-XII вв., а также их легендарных предшественников, которые, в представлении летописца, правили огромной страной, якобы охватывавшей все восточное побережье Адриатики от Винодола до Диррахия с прилегающими областями далматинского хинтерланда. История этого воображаемого королевства, из которого в представлении летописца постепенно выросла современная ему Дуклянская держава, начинается в летописи с рассказа о трех братьях - сыновьях готского короля Сенулада, появление которых на исторической сцене датируется летописцем посредством упоминания ряда известных исторических фигур, действовавших в конце $\mathrm{V}$ - первой половине VI века [2, с. 293]. В то время как старший брат, Брус, по сообщению летописца, унаследовал трон отца в некой северной стране готов, двое младших братьев, Тотила и Остроил, отправились покорять новые земли. После победы над войсками «королей» Далмации и Истрии готы разделились: Тотила ушел в Италию, а Остроил, вступив в Иллирийскую провинцию, овладел всей Далмацией и приморскими областями [2, с. 293-296]. Обосновавшись в Превалитанской области, Остроил и стал основателем династии королей, деяния которых описываются в последующих главах летописи. 
Начало дуклянской истории в том виде, в каком оно предстает в летописи, сложно трактовать иначе, нежели как «изобретенную традицию», в рамках которой ранняя история Дукли фактически рассматривается как история готского королевства. Так, изложенная в летописи история трех сыновей Сенулада, как заметил Й. Рус, напоминает повествование готского историка Иордана о трех сыновьях Вандалария, что позволяет предположительно говорить об искаженном воспроизведении в первых трех главах летописи истории рода Амалов, начиная с периода существования их королевства в Паннонии (454-471 гг.) $[21$, s. 33]. При том что история деяний Тотилы и Остроила являлась сложносоставной историографической конструкцией, важно подчеркнуть, что, как и в случае со сплитской традицией, сама по себе апелляция летописца к готам была порождением не славянской, а романской среды, ведь Бар, независимо от высокой степени своей интеграции в политическое пространство Дукли, где он фактически играл роль столицы, оставался (по крайней мере, отчасти) романским по населению городом.

Хотя у нас не может быть уверенности в том, что в Баре славян, подобно тому, как это было в Сплите, называли готами, версия, согласно которой в романской среде восточного побережья Адриатики выработалось единое обозначение славяноязычных жителей, основанное на противопоставлении римлян и готов, представляется правдоподобной. Вместе с тем созданный в Баре исторический нарратив, вероятно, служил интересам дуклянской династии Воиславичей, объединившей под своей властью ряд славянских княжеств и создавшей в XI-XII вв. могушественное «Королевство славян» [11, s. 125-135]. В подтверждение данной мысли можно привести тот факт, что на страницах летописи в конструирование дуклянской истории оказались вовлечена не только готская, но и славянская традиция, связанная с Великой Моравией: так, король, в правление которого, согласно летописи, произошло крещение готско-славянского королевства, носит имя Светопелек, заставляющее вспомнить моравского князя Святополка (871-894 гг.), причем крестителем короля и его подданных выступает не кто иной, как изобретатель славянской азбуки Константин (Кирилл) [2, с. 300-302]. Таким образом, барский священник конструирует дуклянскую историю, выстраивая ее в соответствии с актуальными для этого уголка Средиземноморья обозначениями, одно из которых было «готы», а другое - «славяне».

Но в каком именно соотношении друг с другом находились понятия «готы» и «славяне»? С одной стороны, может показаться, что летописец прямо отождествлял одних с другими. Так, во введении он сообщает о том, что его труд включает в себя (или целиком представляет собой) сделанный им перевод со славянского языка некой (возможно, им же ранее и написанной) «Книги о готах», именуемой по-латыни «Королевством славян» ${ }^{2}$, а повествуя о том, как в правление короля Бладина территорию по соседству с готами заняли переселенцы с реки Волги, называемые «вулгарами» (Vulgari), летописец счел нужным отметить: «И оба народа весьма почитали друг друга - готы, то есть славяне, и вулгары, и главным образом из-за того, что те и другие были язычники и одного языка» $[1$, с. 50]. С другой стороны, название «готы» используется только в начальных главах летописи, в то время как в последующих говорится лишь о славянах. Более того, в главе, рассказывающей о правлении Силимира (отца Бладина), сообщается о том, что этот король «наполнил страну множеством славян» [2, с. 297], словно между готами и славянами все же существовала какая-то разница.

Интересно, что похожее явление наблюдается и в труде Фомы Сплитского. Как заметил Л. Маргетич, анализируя рассказ сплитского автора о разорении Салоны, при том что Фома Сплитский, казалось бы, повествует об одном историческом эпизоде, в используемых им определениях заметна хронологическая последовательность: если в начале своего повествования о варварах, разоривших Салону, он именует их преимущественно готами, то впоследствии все чаще говорит о славянах, а под конец начинает повсеместно использовать название «хорваты» [15, s. 11-13]. Подобная непоследовательность в использовании понятия «готы» не что иное, как зримое свидетельство трудностей, с которыми столкнулись средневековые авторы, пытаясь при- 
вести обиходное, обусловленное сугубо локальным контекстом, квазиэтническое понятие в соответствие с полноценным этническим дискурсом, в рамках которого готы должны были быть изображены как особый народ, связанный общностью происхождения и истории.

Появление в позднее Средневековье, вероятно, в XIV в., в Хорватии славянской редакции Летописи попа Дуклянина - Хорватской хроники - стало первым опытом апроприации характерного для романцев готского дискурса в среде самих славян. Интересно, что при этом историческая схема дуклянского автора подверглась изменениям. Изложение событий в Хорватской хронике соответствует (с некоторыми более или менее существенными расхождениями в отдельных деталях) лишь первым 23 главам из 47 дуклянского автора с присоединением к ним еще нескольких глав (24-28) с содержанием, не имеющим параллелей в латинской редакции. При этом, вопреки концепции дуклянского автора, считавшего преемниками готских королей травунских, а затем дуклянских правителей, в Хорватской хронике в роли такого преемника выступает хорватский король Звонимир (1075-1089 гг.), о правлении которого подробно рассказывается в ее последних главах. В хронике исчезает и географическая привязка «готско-славянского» королевства к Травунии и Дукле, ясно читаемая в названиях местностей и населенных пунктов, фигурирующих в латинской редакции $[18$, s. $22-23,58-$ 60]. Если, согласно латинской редакции, ядром основанного Остроилом королевства была «Превалитанская область» (то есть позднеантичная провинция Превалис, территориально приблизительно соответствовавшая Дукле), то в Хорватской хронике вместо нее фигурирует некий «Приливит», прямо локализуемый автором хроники в Боснии [2, с. 387]. Интересно, что король, при котором произошло крещение, в Хорватской хронике именуется не Светопелеком, а - по причине, до сих пор остающейся невыясненной - Будимиром [2, с. 392-394], то есть именем, более соответствующим хорватской антропонимии.

При этом важно подчеркнуть, что отразившееся в Хорватской хронике представление о готских истоках Хорватского королев- ства не означало характерного для романских городов приписывания готского происхождения самому народу хорватов. Так, при описании битвы готов с «королем Истрии», автор Хорватской хроники, сообщая о гибели от меча готов множества христиан, счел нужным специально упомянуть среди жертв поражения хорватов («i vele Hrvat bi pobijeno») [2, с. 385]. Следовательно, автор хроники считал хорватов не готами, а автохтонными жителями Далмации и Истрии. Примечательно при этом, что название «славяне» на страницах хроники также не используется: не нуждаясь в приписывании хорватам пришлого происхождения, автор хроники точно так же не испытывал ни малейшей потребности в том, чтобы применять к хорватам этнические категории, характерные для этнического дискурса далматинских романцев, будь то «готы» или «славяне».

С картиной, вырисовывающейся из известий Хорватской хроники, контрастирует историография далматинских городов, где, несмотря на далеко зашедшие процессы языковой славянизации горожан, традиция отождествления славян с готами и противопоставления их горожанам как потомкам римлян сохранялась еще в эпоху позднего Ренессанса. Свидетельством тому может служить труд Людовика Цриевича-Туберона (14581527 гг.) «Комментарии о моем времени» [8], где славянам приписывается готское происхождение. При этом дубровницкий автор, в распоряжении которого, как он сам отмечает, находилась Летопись попа Дуклянина, апеллировал не только к письменным источникам, но и к таким фактам, как, например, именование славян «тотами» (в интерпретации Туберона - готами!) в венгерском языке, или использование определения «готский» в живой речи Дубровника по отношению к рабыням-славянкам.

Вместе с тем именно в эпоху позднего Ренессанса критерии этнической принадлежности, основанные на общности языка, стали составлять серьезную конкуренцию линиям размежевания, основанным на политической принадлежности, что, если воспользоваться удачным выражением Б. Андерсона, отвечало новому «стилю воображения» социальной реальности. Зародившийся в эту эпоху прото- 


\section{ВСЕОБЩАЯ ИСТОРИЯ}

национальный дискурс стал ментальным ответом интеллектуалов на потребность в новых формах групповой идентификации, соответствовавших менявшемуся мировоззрению социальной элиты. Применительно к хорватским землям это означало выдвижение на первый план славянской языковой принадлежности жителей как приморской Далмации, так и хинтерланда, вследствие чего дискурсивное противопоставление друг другу автохтонов далматинцев и славян-готов постепенно стало отходить на второй план. Так, уже в трактате далматинского гуманиста Юрая Шижгорича «О положении Иллирии и о городе Шибенике» (1487 г.) [23], где славяноязычные далматинцы выступают как часть более широкой «воображаемой общности» - «иллирского народа», готы (отождествляемые при этом с гетами!) рассматриваются (наряду с куретами Фомы Сплитского, давшими название хорватам) лишь как один из иллирских народов. Именно в работе Шижгорича были заложены основы иллиризма - идеологемы, утверждавшей - в отличие от средневековой готской традиции - местные, иллирийские, истоки славянской общности [6, s. 117-125].

Это смещение акцента с противопоставления жителей далматинских городов населению хинтерланда на общие истоки славяноязычного населения Далмации не могло не сказаться и на трактовке образа готско-славянского королевства, который обрел новую жизнь в период Чинквеченто благодаря обнаружению в 1500 г. Д. Папаличем в Краине (Макарское приморье) списка Хорватской хроники, который, по его просьбе, был переведен на латынь сплитским гуманистом Марко Маруличем [16, s. 171-225]. Хотя Марулич не вкладывал в свой текст политического смысла, полагая, что знакомство с деяними королей будет играть роль морального назидания для читателей [12, s. 134], созданный им перевод оказался востребованным в условиях зарождения в венецианской Далмации и Дубровнике протонациональной идеологии, осмыслявшей славянскую языковую общность в рамках ренессансного этнического дискурса. Так, уже гуманист Винко Прибоевич, живописуя в своей речи «О происхождении и славе славян», произнесенной им в 1525 г. в городе Хвар, доблесть древних славянских правителей, ссылал- ся на пример одного из известных ему по переводу Марулича персонажей - победоносно сражавшегося с «гуннами» (венграми) короля Полислава, именуя его при этом не готским или славянским королем, а королем иллиров $[19$, s. 72$]$.

Реабилитация имени варваров-славян (через привязку их к иллирам), осуществленная Прибоевичем (подробнее см.: [14]), создала благоприятную среду и для возвеличивания готов в качестве (одних из) их предков. Произошло это, впрочем, уже в иных исторических условиях, когда готицизм успел занять прочное место в кругу протонациональных идеологем. Основоположником «готского возрождения» в историографии стал дубровницкий историк Мавро Орбини, который в своем труде «Королевство славян» (1601 г.) сумел поставить старинное представление о связи славян с готами на службу глорификации славянства как доблестного народа завоевателей [3]. Готские сюжеты Летописи попа Дуклянина, опубликованной в книге Орбини в переводе на итальянский язык, органично сочетались с разработанной автором концепцией истории славян, важная роль в которой отводилась исходу славян со своей прародины, локализованной Орбини в Скандинавии, то есть там, где средневековая традиция размещала родину готов. Однако, считая готов лишь одним из славянских народов, Орбини рассматривал основанное ими королевство в Далмации не как начало славянской истории, что заметно отличало его концепцию от воззрений его предшественника Туберона, а как связующее звено между античным периодом, когда, в его представлении, унаследованном от Прибоевича, Иллирик уже являлся славянским, и более поздними славянскими монархиями, существовавшими на Балканах, в первую очередь Сербским царством $[5$, s. 108,178$]$. В грандиозной версии славянской истории, сконструированной Орбини, готские короли стали наследниками римских императоров и предшественниками средневековых монархов, обеспечивая политическую преемственность.

Явственно обозначенная в труде Орбини историческая схема, в рамках которой готско-славянское королевство потомков Сенулада выполняло роль связующего звена меж- 
ду античным Иллириком и славянскими монархиями Средневековья, оказала влияние на историографию эпохи барокко. Фактически она стала канонической для исторической литературы XVII-XVIII вв., при том что интерпретация готско-славянского королевства в актуальных для данной эпохи этнических или этнополитических категориях заметно варьировалась от автора к автору. Для нас в данном случае важно подчеркнуть то, что готско-славянское королевство органично вошло в формирующийся хорватский национальный исторический нарратив, в рамках которого образ готской династии приобрел коннотации, ранее ему не присущие.

Так, одним из первых трудов, в которых история готско-славянского королевства была представлена как часть собственно хорватской истории, стал труд хорватского аристократа Юрая Ратткая «История королей и банов королевств Далмации, Хорватии и Славонии» (1652 г.) [20], где деяния потомков Сенулада воспроизводились главным образом в соответствии с латинским переводом Хорватской хроники, выполненным М. Маруличем, но и с использованием труда М. Орбини. Примечательно, что Ратткай отнюдь не ограничился пересказом Хорватской хроники, а наполнил повествование массой уточняющих деталей, впервые в историографии предложив точные датировки правления готских королей. Сфокусировав внимание на их роли в хорватской истории, Ратткай особое внимание уделил Будимиру, правление которого он датировал периодом с 641 по 681 г.: в изображении Ратткая этот король представал «апостолом Хорватии», сделавшим для Хорватского королевства то же, что спустя несколько веков осуществит для Венгрии Иштван (Стефан) [20, s. 144-148]. Уподобление Будимира Иштвану находилось в русле политических взглядов Ратткая, его стремления представить Хорватию равноправным партнером Венгерского королевства [5, s. 284-285].

Большую роль сыграли элементы готицизма и в исторической концепции хорватского историка Павла Риттера-Витезовича, в трудах которого содержались уже все необходимые элементы для концептуализации хорватской общности как национальной [7, s. 68-70; 24]. В своем труде «Хроника или история веков всего света», опубликованном в 1696 г. на хорват- ском языке и служившем тем самым целям ознакомления с историей широкого круга читателей [25], Витезович при описании средневекового прошлого главным образом воспроизводил труд своего предшественника Антуна Врамца (1578 г.), чье этническое самосознание и видение истории определялось его принадлежностью к уходящему своими корнями в Средневековье этногеографическому региону «Словенская земля» (в юго-западной части Карпатской котловины). Витезович значительно модифицировал историческую схему Врамца, дополнив известия, касавшиеся «Словенской земли», информацией о других областях хорватского исторического пространства, в частности введя в повествование информацию о готских королях, почерпнутую им из трудов предшественников. В более позднем, латиноязычном, сочинении Витезовича «Возрожденная Хорватия» (1700 г.) [26], призванном обосновать территориальные притязания монархии Габсбургов при определении новой границы с Османской империей, автор снова обращается к готско-славянскому королевству, при этом уже не просто отождествляя его с Хорватией, но и используя его историю для обоснования государственной традиции Хорватии в ее «исторических» границах: основание Хорватского королевства Витезович связывает с правлением готского короля Остривоя (летописного Остроила). Витезович полностью интегрировал готские элементы в создаваемую им идеологическую концепцию Хорватского королевства (см. о ней: [6]), использовав этнические, географические и политические аспекты готской темы для ее проработки.

Таким образом, можно заключить, что хорватский готицизм отнюдь не являлся стабильной идеологической конструкцией. Вопреки распространенному в историографии представлению о том, что готицизм был призван, прежде всего, возвеличить народ или правящую династию, представление о связи хорватов и готов было более сложным и многомерным, питаясь разными мотивами, отнюдь не сводимыми к одной глорификации. История готицизма в Хорватии началась с приписывания хорватам готского происхождения в романоязычной городской среде далматинского побережья. Это явление можно объяснить, если обратиться к основополагающим 
маркерам хорватской идентичности в представлении романоязычных жителей: подобно готам, хорваты осуществляли политический контроль в областях далматинского хинтерланда, говорили на варварском языке и имели варварские обычаи. В этом смысле образ готов был просто образом варваров - завоевателей внутренних областей Далмации. Произошедшее в позднее Средневековье усвоение готской традиции в Хорватском королевстве, очевидно, объяснялось необходимостью его политической легитимизации: готы, а точнее готские короли, рассматривались как основатели державы, причем их готское происхождение, судя по всему, не играло большой роли для данного политического дискурса. Наконец, в эпоху Ренессанса в функционировании готицизма происходит очередная перемена: готы были осмыслены и репрезентированы в категориях протонационального дискурса как народ, обладавший древней историей и государственностью. Именно в таком «этнополитическом» качестве, а не как варвары или завоеватели, готы оказались востребованы авторами, выстраивавшими дискурсивные образы славянской, «иллирской», а позднее собственно хорватской нации.

\section{ПРИМЕЧАНИЯ}

${ }^{1}$ Исследование выполнено за счет гранта Российского научного фонда, проект № 16-18-10080 «"Мобилизованное средневековье”: обращение к средневековым образам в дискурсах национального и государственного строительства в России и странах Центрально-Восточной Европы и Балкан в Новое и Новейшее время».

${ }^{2}$ «...ut Libellum Gothorum quod latine Sclavorum dicitur regnum, quo omnia gesta ac bella eorum scripta sunt, ex sclavonica littera verterem in latinam...» [6, с. 292]. Если принять конъектуру К. Шегвича, заменив «regnum» на «regum», то перевод может быть и таким: «книгу готских, что полатыни означает “славянских”, королей». Такое чтение кажется логичным в свете слов летописца о том, что в книге описываются «их деяния и войны» [22].

\section{СПИСОК ЛИТЕРАТУРЫ}

1. Алексеев, С. В. Летопись попа Дуклянина. Перевод и комментарий / С. В. Алексеев. - СПб. : Петербургское Востоковедение, 2015. - 288 с.
2. Летопис Попа Дукљанина / уредио Ф. Шишић. - Београд ; Загреб : Заклада тискаре Народних новина, 1928. $-480 \mathrm{c}$.

3. Орбини, М. Славянское царство. Происхождение славян и распространение их господства / М. Орбини ; пер. Ю. Куприкова. - М. : ОЛМА Медиа Групп, 2010. -575 с.

4. Фома Сплитский. История архиепископов Салоны и Сплита / Фома Сплитский ; вступ. ст., пер., коммент. О. А. Акимовой. - М. : Индрик, 1997. $-320 \mathrm{c}$.

5. Blažević, Z. Ilirizam prijeilirizma/Z. Blažević. Zagreb : Golden marketing - Tehnička knjiga, 2008. $400 \mathrm{~s}$.

6. Blažević, Z. Vitezovićeva Hrvatska između stvarnosti i utopije: ideološka koncepcija u djelima postkarlovačkog ciklusa Pavla Rittera Vitezovića (1652-1713) / Z. Blažević. - Zagreb : Barbat, 2002. $279 \mathrm{~s}$.

7. Cipek, T. Oblikovanje hrvatskog nacionalnog identiteta. Primordijalni identitetski kod u ranoj hrvatskoj političkoj misli / T. Cipek // Dijalog povjesničara-istoričara / ur. I. Graovac, H.-G. Fleck. Zagreb : Friedrich Naumann Stiftung, 2001. - S. 59-75.

8. Crijević Tuberon, L. Komentari o mojem vremenu / L. Crijević Tuberon ; uvodna studija, prijevod latinskog izvornika i komentar V. Rezar. Zagreb : Hrvatski institut za povijest, 2001. - 341 s.

9. Documenta historiae chroaticae periodum antiquam illustrantia / collegit, digessit, explicuit Dr F. Rački. - Zagrabiae : Jugoslavenska akademija znanosti i umjetnosti, 1877. -544 p.

10. Gunjača, S. Ispravci i dopune starijoj hrvatskoj historiji / S. Gunjača. - Zagreb : Školska knjiga, 1973. - Kn. I. Izvori (Analiza i kritika). - 462 s.

11. Homza, M. [et al.]. Svatopluk v europskom pisomnictve. Študie z dejin svatoplukovskej legendy / M. Homza [et al.]. - Bratislava : Post Scriptum, 2013. $749 \mathrm{~s}$.

12. Jovanović, N. Marulićev prijevod Hrvatske kronikei ovo izdanje/N. Jovanović// Marulić M. Latinska manja djela II. - Split : Književni krug, 2011. -S. 125-168.

13. Katičić, R. Vetustiores ecclesiae spalatensis memoriae / R. Katičić // Starohrvatska prosvjeta. Ser. III. - 1987. - Sv. 17. - S. 17-51.

14. Madunić, D. Strategies of distinction in the work of Vinko Pribojević / D. Madunić // Whose love of which country? Composite states, national histories and patriotic discourses in Early Modern East Central Europe / ed by B. Trencsényi, M. Zászkaliczky. Leiden ; Boston : Brill, 2010. - P. 177-202.

15. Margetić, L. Historia Salonitana i Historia Salonitana Maior - neka pitanja / L. Margetić // Historijski zbornik. - 1994. - God. XLVII(1). -S. 1-36.

16. Marulić, M. Latinska manja djela II / M. Marulić. - Split : Književni krug, 2011. - 308 s. 
17. Matijević Sokol, M. Toma Arhiđakon i njegovo djelo: rano doba hrvatske povijesti / M. Matijević Sokol. - Jastrebarsko : Naklada Slap, 2002. - 385 s.

18. Mužić, I. Hrvatska kronika u Ljetopisu Popa Dukljanina / I. Mužić. - Split : Muzej hrvatskih arheoloških spomenika, 2011. - 343 s.

19. Pribojević, V. O podrijetlu i slavi Slavena / V. Pribojević ; preveli V. Gortan, P. Knezović. Zagreb : Golden marketing : Narodne novine, 1997.$211 \mathrm{~s}$.

20. Rattkay, J. Spomen na kraljeve i banove Kraljevstava Dalmacije, Hrvatske i Slavonije / J. Rattkay ; preveli Z. Blažević, V. Rezar, B. Nikšić, T. Shek Brnardić, I. Miličić. - Zagreb : Hrvatski institut za povijest : Sveučilište u Zagrebu - Hrvatski studij, 2016. - 374 s.

21. Rus, J. Kralji dinastije Svevladičev, najstarejši skupni vladarji Hrvatov in Srbov 454-614 / J. Rus. Ljubljana : Univerzitetna tiskarna J. Blasnika, 1931.$208 \mathrm{~s}$.

22. Šegvić, K. Hrvat, Got i Slav u djelu Tome Splićanina / K. Šegvić // Hrvati i Goti / priredio R. Tafra. - Split : Iberia, 1996. - S. 193-198.

23. Šižgorić, J. O smještaju Ilirije i o gradu Šibeniku / J. Šižgorić ; priredio i preveo V. Gortan. - Šibenik : Muzej grada Šibenika, 1981. - 122 s.

24. Topić, M. Nacionalizam i ideologija. Pavao Ritter Vitezović kao nacionalni mislitelj i/ili ideolog / M. Topić // Zbornik Odsjeka povijesnih znanosti Zavoda za povijesne i društvene znanosti HAZU. 2010. - Sv. 28. - S. 107-138.

25. Vitezović Ritter, P. Kronika aliti Spomen vsega svieta vikov: 1696 / P. Ritter Vitezović ; priredio A. Jembrih. - Zagreb : ArTresor naklada, 2015. -626 s.

26. Vitezović Ritter, P. Oživljena Hrvatska / P. Ritter Vitezović ; prevela i priredila Z. Blažević. - Zagreb : Latina et Graeca : Hrvatski institut za povijest : Zavod za hrvatsku povijest Filozofskog fakulteta, 1997. - $173 \mathrm{~s}$.

\section{REFERENCES}

1. Alekseev S.V. Letopis popa Duklyanina. Perevod $i$ kommentariy [Chronicle of the Priest of Dioclea. Translation and Commentary]. Saint Petersburg, Peterburgskoe Vostokovedenie Publ., 2015. 288 p.

2. Šišić F., ed. Letopis Popa Duklyanina [The Chronicle of the Priest of Dioclea]. Belgrade; Zagreb, Narodne novine Publ., 1928. 480 p.

3. Orbini M. Slavyanskoe tsarstvo. Proiskhozhdenie slavyan i rasprostranenie ikh gospodstva [The Kingdom of Slavs. The Origin of the Slavs and Their Expansion]. Moscow, OLMA Media Group Publ., 2010. $575 \mathrm{p}$.

4. Foma Splitskiy. Istoriya arkhiepiskopov Salony $i$ Splita [History of Bishops of Salona and Split]. Moscow, Indrik Publ., 1997. 320 p.
5. Blažević Z. Ilirizam prije ilirizma [Illyrianism Before Illyrianism]. Zagreb, Tehnička knjiga Publ., 2008. 400 p.

6. Blažević Z. Vitezovićeva Hrvatska između stvarnosti i utopije: ideološka koncepcija u djelima postkarlovačkog ciklusa Pavla Rittera Vitezovića (1652-1713) [Vitezović's Croatia Between Reality and Utopia. Ideological Conception in the Post-Karlowitz Cycle of Writings by Pavao Ritter Vitezović (16521713)]. Zagreb, Barbat Publ., 2002. 279 p.

7. Cipek T. Oblikovanje hrvatskog nacionalnog identiteta. Primordijalni identitetski kod u ranoj hrvatskoj političkoj misli [Formation of the Croatian National Identity. Primordial Identity Code in the Early Croatian Political Thought]. Graovac I., Fleck H.-G., eds. Dijalog povjesničara-istoričara [Dialogue of Historians]. Zagreb, Friedrich Naumann Stiftung Publ., 2001, pp. 59-75.

8. Crijević Tuberon L. Komentari o mojem vremenu [Commentaries on my Time]. Zagreb, Croatian Institute of History Publ., 2001. 341 p.

9. Rački F., ed. Documenta historiae chroaticae periodum antiquam illustrantia [Documents Elucidating the Ancient Period of Croatian History]. Zagreb, Jugoslavenska akademija znanosti i umjetnosti Publ., 1877. 544 p.

10. Gunjača S. Ispravci i dopune starijoj hrvatskoj historiji. Knj. I. Izvori (Analiza i kritika) [Corrections and Additions to the Earlier Croatian History. Vol. I. Primary Sources (Analysis and Critique)]. Zagreb, Školska knjiga Publ., 1973. Kn. I. Izvori (Analizai kritika). 462 p.

11. Homza M., et al. Svatopluk v europskom pisomnictve. Študie z dejin svatoplukovskej legendy [Svatopluk in European Literature. Studies on the History of the Svatopluk Legend]. Bratislava, Post Scriptum Publ., 2013. 749 p.

12. Jovanović N. Marulićev prijevod Hrvatske kronike i ovo izdanje [Marulić's Translation of the Croatian Chronicle and its Edition]. Marulić M., ed. Latinska manja djela II [Latin Little Works II]. Split, Književni krug Publ., 2011, pp. 125-168.

13. Katičić R. Vetustiores ecclesiae spalatensis memoriae. Starohrvatska prosvjeta. Ser. III, 1987, Sv. 17, pp. 17-51.

14. Madunić D. Strategies of distinction in the work of Vinko Pribojević. Trencsényi B., Zászkaliczky M., eds. Whose love of which country? Composite states, national histories and patriotic discourses in Early Modern East Central Europe. Leiden; Boston, Brill Publ., 2010, pp. 177-202.

15. Margetić L. Historia Salonitana i Historia Salonitana Maior - neka pitanja [Historia Salonitana and Historia Salonitana Maior: Some Questions]. Historijski zbornik, 1994, vol. XLVII (1), pp. 1-36.

16. Marulić M. Latinska manja djela II [Shorter Latin Works II]. Split, Književni krug Publ., 2011. 308 p. 


\section{ВСЕОБЩАЯ ИСТОРИЯ}

17. Matijević Sokol M. Toma Arhiđakon i njegovo djelo: rano doba hrvatske povijesti [Thomas the Archdeacon and His Work: Early Period of Croatian History]. Jastrebarsko, Naklada Slap Publ., 2002. $385 \mathrm{p}$.

18. Mužić I. Hrvatska kronika u Ljetopisu Popa Dukljanina [The Croatian Chronicle in the Chronicle of the Priest of Dioclea]. Split, Muzej hrvatskih arheoloških spomenika, 2011. 343 p.

19. Pribojević V. O podrijetlu i slavi Slavena [On the Origin and Glory of the Slavs]. Zagreb, Narodne novine Publ., 1997. 211 p.

20. Rattkay J. Spomen na kraljeve $i$ banove Kraljevstava Dalmacije, Hrvatske $i$ Slavonije [Memory of Kings and Bans of the Kingdoms of Croatia, Slavonia, and Dalmatia]. Zagreb, Hrvatski institut za povijest : Sveučilište u Zagrebu - Hrvatski studij, 2016. 374 p.

21. Rus J. Kralji dinastije Svevladičev, najstarejši skupni vladarji Hrvatov in Srbov 454614 [Kings of the Svevlad Dynasty, the Oldest Common Rulers of the Croats and Serbs]. Ljubljana, Univerzitetna tiskarna J. Blasnika, 1931. 208 p.
22. Šegvić K. Hrvat, Got i Slav u djelu Tome Splićanina [A Croat, a Goth, and a Slav in the Work of Thomas the Archdeacon]. Tafra R., ed. Hrvati $i$ Goti [Croats and Goths]. Split, Iberia Publ., 1996, pp. 193-198.

23. Šižgorić J. O smještaju Ilirije $i$ o gradu Šbeniku [Concerning the Location of Illyria and the Town of Pibenik]. Šibenik, Muzej grada Šibenika, 1981. $122 \mathrm{p}$.

24. Topić M. Nacionalizam i ideologija. Pavao Ritter Vitezović kao nacionalni mislitelj i/ili ideolog [Nationalism and Ideology. Pavao Ritter Vitezović as a National Thinker or/and an Ideologist]. Zbornik Odsjeka povijesnih znanosti Zavoda za povijesne $i$ društvene znanosti HAZU, 2010, vol. 28, pp. 107-138.

25. Vitezović Ritter P. Kronika aliti Spomen vsega svieta vikov: 1696 [Chronicle or History of the Whole World Centuries: 1696]. Zagreb, ArTresor Publ., 2015. $626 \mathrm{p}$.

26. Vitezović Ritter P. Oživljena Hrvatska [Revived Croatia]. Zagreb, Latina et Graeca: Hrvatski institut za povijest : Zavod za hrvatsku povijest Filozofskog fakulteta, 1997. $173 \mathrm{p}$.

\section{Information about the Author}

Denis E. Alimov, Candidate of Sciences (History), Associate Professor, Department of History of Slavic and Balkan Countries, Saint Petersburg State University, Universitetskaya Emb., 7/9, 199034 Saint Petersburg, Russian Federation, d.alimov@spbu.ru, http://orcid.org/0000-0002-4733-4150.

\section{Информация об авторе}

Денис Евгеньевич Алимов, кандидат исторических наук, доцент кафедры истории славянских и балканских стран, Санкт-Петербургский государственный университет, Университетская наб., 7/9, 199034 г. Санкт-Петербург, Российская Федерация, d.alimov@spbu.ru, http://orcid.org/ 0000-0002-4733-4150. 